\title{
Covid-19 i svenska skolor synliggör sårbarhetens potential i lärares praktik
}

\author{
Linda Ekström Lind \\ Anna Martín Bylund \\ Linnéa Stenliden
}

\author{
Folkungaskolan, Linköping \\ Linköpings universitet \\ Linköpings universitet
}

När covid-19-pandemin skakar utbildningssystemet i grundvalarna angrips inte bara elever och lärare utan också de pågående processer som skapas i utbildningens relationella spänningsfält. Syftet med denna text är att belysa lärares förmåga att ta in och agera i den unika fysiska och digitala kontext som uppstår. Studien genomfördes mellan 19 mars och 19 april 2020. Genom dagboksanteckningar och reflektionsnoteringar dokumenterade fem svensklärare sin skolvardag under denna tid. Med hjälp av begreppet respons- och ansvarskapabel pedagogik analyseras de förändrade processerna och lärares agerande. Studien visar att de komplexa händelserna aktiverar lärares känslighet för sina inneboende förmågor och sin moraliska kompass. Med andra ord, de sociala, politiska och materiella relationer som uppstår påverkar lärares etisk-politiska praktik. Det blir än mer centralt att vara uppmärksam, nyfiken och agera ansvarsfullt. En sådan respons- och ansvarskapabel pedagogik förstärks alltså när den gängse lärarpraktiken delvis är satt ur spel. Avslutningsvis diskuteras hur undervisningen ska bedrivas framöver. Hur ska vi tänka när skolan fortsätter att innebära en turbulent tillvaro?

\section{Inledning}

När covid-19-pandemin drabbar världen påverkas våra livsvillkor i grunden. Den 23 april 2020 berörs cirka $90 \%$ av eleverna i olika skolformer i 191 länder1. I Sverige stängs verksamheten i universitetens, vuxenutbildningens och gymnasieskolornas lokaler och regeringen meddelar att distansundervisning ska bedrivas. Grundskolorna förbereder sig på en skolstängning, medan verksamheten också fortsätter som vanligt2. Hur hanterar lärare denna oväntade situation?

Högstadieläraren Sofia, som varit på studieresa med sina elever i slutet av februari, börjar bli orolig.

\footnotetext{
"Jag börjar misstänka att min lätta förkylning trots allt skulle kunna vara en samhällsfarlig virussjukdom. Det är torsdag morgon och samtidigt som mina kollegor nu tvingas genomföra nationella prov digitalt utan mig ska jag ta prover på sjukhuset. En kollega ringer när jag sitter i bilen och är uppstressad över att tekniken inte fungerar. Jag står uppskriven som teknisk support på informationen lärarna har fått, men jag har ingen möjlighet att hjälpa och måste lämna min kollega att lösa problemet själv. Det är fredag morgon när telefonen ringer och infektionskliniken meddelar mig att mitt provsvar för covid-19 kommit tillbaka positivt.
}

Det som händer de följande dagarna är utom min kontroll, eftersom jag nu ska hållas isolerad i hemmet. Jag är en av de första att konstateras smittad i regionen, och oron stiger snabbt på min arbetsplats, både bland elever, vårdnadshavare och kollegor. De första dagarna under min frånvaro, som ska komma att sträcka sig över en hel månad, är 17 lärare 
borta och många elever hålls hemma. [...] Mina kollegor får samtidigt i uppdrag att förbereda för omställning till distansundervisning och skapar nya digitala miljöer för eleverna att vistas i vid händelse av stängning."

Högstadieläraren Sofia

Ett virus skakar hela utbildningssystemet i grundvalarna, vilket metaforiskt kan liknas vid skolans "svarta svan". En sådan symboliserar en ovanlig och oförutsedd händelse som visar sig få mycket stor inverkan på våra liv [1]. Omställningen till distansutbildning kan liknas vid en sådan oförutsedd händelse som får stora effekter på skolan och troligen kommer påverka utbildningssystemet framöver. När viruset infiltrerar utbildningssystemet angrips inte bara lärare och elever, utan även de pågående processer som skapas i utbildningens relationella spänningsfält [2]. Det är i detta spänningsfält av relationer som utbildningen skapas i ett bestämt nu, som en glödande brännpunkt i skolans praktik. Här förändras dessa relationer. De omformas (blir digitala) och de förflyttas (utanför klassrummen). På så sätt upplöses de rum där kunskapsutvecklingen normalt sker. Praktiken blir tillfälligt näst intill oigenkännbar då undervisningen helt eller delvis sker via digitala hjälpmedel på distans. Övergången sker snabbt och oväntat och i lärarnas arbete blir allt ett stort, obegränsat pågående nu. Viruset skapar oreda på gymnasieskolorna, men även inom grundskolan där verksamheten ska pågå "som vanligt" och samtidigt förbereda för en stängning. Allt är kaotiskt, påtagligt nu-varande och samtida.

Samtidigt ger oss händelsen en unik möjlighet att få syn på sådant som tidigare gjorts. När allt ställs på sin spets kan sårbarhetens potential i lärarrollen bli synlig, vilket kan ge nya kunskaper om yrket och undervisningen. Därför undersöker vi i denna studie hur grund- och gymnasielärares professionella agerande framträder när ett virus upplöser skolans tid och rum. Syftet är att belysa lärares förmåga att ta in den unika fysiska och digitala kontexten, utforska det okända och anpassa sina handlingar utifrån vad situationen kräver. Med andra ord är fokus för denna text lärares praktik i det relationella spänningsfält som utgör undervisning och skola under inledningen av covid-19-pandemin i Sverige.

Studien genomfördes mellan 19 mars och 19 april 2020 inom ramen för det nationella projektet "Utbildning, lärande och forskning" (ULF). Forskargruppen består av tre högstadielärare och två gymnasielärare, med 2-20 års erfarenhet av läraryrket, samt två forskare i pedagogiskt arbete. Under pandemins inledande skede dokumenterade lärarna individuellt vad de upplevde i skolvardagen med hjälp av dagboksanteckningar och reflektionsnoteringar. Detta empiriska material analyserades sedan gemensamt av alla i forskargruppen. Vi har följt Vetenskapsrådets riktlinjer för god forskningssed [3]. De deltagande lärarna har alla informerats om studien, gett samtycke till det frivilliga deltagandet och vet att deltagandet när som helst kan avbrytas. I studien är de deltagande lärarna delvis också forskare vilket gör att de eventuellt kan identifieras. Lärarna har dock getts fiktiva namn i denna text för att bidra till anonymitet. De har också fått möjlighet att kommentera och göra klargöranden innan publicering.

\section{Lärares etisk-politiska praktik}

När covid-19 är en realitet behöver alla agera i det oväntade och annorlunda utan förberedelse och planläggning. I det kaosartade utbredda nu som uppstår på grund av smittspridningen så förändras, utmanas och intensifieras handlingar och relationer mellan elever, kollegor, diskurser, klassrum, online-undervisning, föräldrar, virus, etcetera [4]. När utgångspunkterna för allas handlingar förändras på detta sätt uppstår också en förskjutning av de sociala, politiska och materiella relationerna. Med hjälp av Bozalek och Zembylas [5] begrepp respons- och ansvarskapabel pedagogik kan denna förskjutning och de förändrade relationella processerna belysas. En sådan pedagogik handlar om att kunna möta en annan skolvardag genom förmåga att orientera sig i, och förhålla sig till en förändrad omgivning. Det innebär att uppmärksamhet och nyfikenhet riktas mot det nya, att ett ansvarstagande uppstår i prekära situationer liksom ett sökande efter ett agerande som syftar till att dugliggöra sig själv och andra. Dessa förmågor står 
naturligtvis hela tiden i relation till varandra. De påverkas, förstärks och försvagas i det relationella samspel som utgör de pedagogiska processerna i skolan. För att som lärare vara förmögen att navigera i det förändrade relationella spänningsfältetunder den speciella tid som råder i svensk skola under covid-19-pandemin krävs en etisk-politisk praktik. Etisk-politiska ställningstaganden behöver hela tiden göras av lärare - hur ska jag agera nu? vad är rätt? vad är fel?

I den följande analysen används begreppen uppmärksamhet, ansvar, nyfikenhet och förmåga att göra (var)andra kapabla för att belysa lärares förmåga att ta in den unika kontexten, utforska det okända och anpassa sina handlingar utifrån vad situationen kräver. Inledningsvis visar vi hur lärarpraktiken förändras och breder ut sig i skolan vid omställningen. Därefter presenterar vi flera konkreta exempel på hur de sociala, politiska och materiella relationer som uppstår påverkar lärares utövande av en respons- och ansvarskapabel pedagogik.

\title{
"Det känns som att jag jobbar gånger fyra just nu"
}

Högstadieläraren Emil beskriver i reflektionsanteckningarna sin lärarvardag på följande vis:

\begin{abstract}
"Förra veckan använde jag tiden till att besvara elevernas funderingar, men idag är det flera lärare som är borta. Någon måste ta deras lektioner. Vanligtvis har jag planeringstid mellan 08:00 och 10:00, men man måste också ställa upp för sina sjuka kollegor och eleverna måste få sin undervisning. Jag känner att jag måste vikariera. [...]
\end{abstract}

\begin{abstract}
En redan stressig tillvaro blir därmed än stressigare när man inte bara ska genomföra den fysiska lektionen, utan också ha tid på sin rast och förtroendetid för att svara på frågor av de elever som är hemma för lite snuva. En fysisk lektion kräver annat än en digital lektion. [...] I mitt fall har jag fått lägga mer tid än vanligt på förarbete, eftersom man i större utsträckning får spela in sig själv, skriva längre texter och svara på mail som inkommit under dagen. Idag har det kommit 37 meddelanden från elever och föräldrar som har frågor. Jag får ta mig tid att svara på dessa efter konferensen som slutar klockan 17:00. När klockan slagit 17:00 tänker jag: 'Nej, jag orkar inte nu. Jag får ta det på vägen hem från jobbet' [...] Vi ska ju förbereda oss för en situation där undervisningen sker via dator och ingen vet hur man bör göra och vad som fungerar bäst i en $100 \%$ digitaliserad undervisning. [...] Det känns som att jag jobbar gånger fyra just nu."
\end{abstract}

\section{Högstadieläraren Emil}

Exemplet visar hur Emil observerar att normala strukturer avseende tid och rum förändras. Det som vi kallar "skola" ska fortfarande fortgå på samma sätt och i samma strukturer som tidigare. Emil agerar utifrån egna ställningstaganden - en etisk-politisk praxis - där han uppmärksammar en socialt och strukturellt förändrad utbildningspraktik. Skolvardagen måste fungera i ett oväntat, ovant och kaotiskt nu, där lärare och elever är sjukanmälda, undervisning ska pågå och allt ska flyta på någorlunda som vanligt. Arbetsbelastningen och stressen ökar och Emil ger av sin tid, handlingskraft och nyfikenhet för att hantera situationen. Interaktionen med elever och vårdnadshavare eskalerar och förändras. Alla parter befinner sig i en upplöst intensifierad tid och möter en skola av också upplösta rum. Detta ändrar förutsättningarna för undervisningen där nya ovana krav skapar ovisshet. Ingen vet säkert. Flera parallella praktiker hanteras samtidigt då Emil genomför undervisning i klassrummet samtidigt som han hjälper hemmavarande elever på distans. Dessutom tar han ansvar för att elevernas undervisningstid garanteras. Emil agerar på samma gång även i relation till att grundskolan helt kan ställas om till distansundervisning.

Arbetsuppgifterna hopar sig och allt manövreras som i ett hoptryckt men samtidigt utbrett nu. Som i en intensiv brännpunkt befinner sig Emil, i en skola där gängse lärarpraktik och strukturer är satta ur spel. 


\title{
Närvarande i frånvaron
}

Elevernas situation under pandemin uppmärksammas av läraren Sofia, trots att hon är drabbad av covid-19 och hemma i karantän.

\begin{abstract}
"Under de första veckorna är det ständigt tal om skolan ska stänga eller inte. Jag undrar under denna tid mycket över mina elevers hemsituation. Om skolan går över till distansundervisning, kommer alla att ha frukost? Vilka elever har ens internet hemma? Har de föräldrar som kan hjälpa dem med rutiner, eller lämnas de vind för våg? De är trots allt inte särskilt stora när de går i årskurs 7-9. [...]"
\end{abstract}

\section{Högstadieläraren Sofia}

När undervisningen förläggs i hemmiljö kan eleverna utlämnas till mindre likvärdiga förutsättningar där inte alla har tillgång till internet eller stöttande vuxna. Sofia antar här en etiskpolitisk inställning då hon funderar kring skolans ansvar gentemot eleverna. Ansvarskänslan Sofia känner skapar en oro för hur eleverna ska hantera sina vardags- och skolrutiner hemifrån, samtidigt som hennes uppmärksamhet riktas mot eventuella likvärdighetsproblem. Likaså riktas hennes fokus mot de förändrade förutsättningarna då både elever och lärare i högre grad antas arbeta hemifrån även vid sjukdom.

\begin{abstract}
"Elever som är hemma sjuka uppmanas att arbeta hemifrån, trots att man vanligtvis ska få lov att vara just sjuk när man är så. Samma sak händer även mig. Trots att jag är sjukskriven och har feber och huvudvärk sätter jag mig framför datorn och försöker följa elevernas utveckling. Det är ju inte så lång tid kvar på terminen."
\end{abstract}

\section{Högstadieläraren Sofia}

Gränserna förskjuts för vad man förväntas göra eller inte göra vid en frånvaro som kan bero på allt från misstänkt smitta, milda symtom till mycket allvarlig sjukdom. Vid distansstudier kan båda parter delta i arbetet i åtskilda rum. Elever kan därmed vara sjuka men också redan friska, ännu inte närvarande men heller aldrig frånvarande. Detta gäller även för lärare och Sofias ansvarskänsla får henne att, i ett kaotiskt nu, agera utöver det vanliga. Hon jobbar hemifrån, trots sjukdom, och inser att även eleverna tvingas studera när de är sjuka. Både lärare och elever bryter på så sätt mot vissa uttalade och outtalade regler för att tillsammans hantera en prekär situation som innebär uppoffring och ansvarstagande, nyfikenhet och omtanke.

Sofias ansvarstagande innefattar även kollegornas situation. Den digitala miljön bekymrar Sofia och hon önskar att hon vore mer behjälplig.

"På min skola är jag en av de ansvariga för den digitala utvecklingen och det är egentligen ödets ironi att jag i det ansträngda läget inte kan vara på plats för att hjälpa mina kollegor. Jag ser ändå att en del av de kollegor som tidigare inte använt den digitala miljön i så hög utsträckning nu verkar mer aktiva. [...]

[...] Kollegors stressnivå ökar markant när de tvingas arbeta både digitalt och analogt, på distans och i klassrummet samt vikariera för frånvarande lärare." 
På distans ser Sofia en ökad stressnivå bland kollegorna när de försöker hantera flera parallella verksamheter där även den digitala miljön ingår. Då vissa kollegor inte har så stor erfarenhet av digitalitet sedan innan ställs nya krav på dem vilket synliggör glappet mellan de som behärskar digitaliseringen och de som inte gör det. Sofia känner ansvar i situationen och upplever att kollegorna skulle behöva henne, men ser också att lärarna på skolan försöker dugliggöra varandra genom att bli mer aktiva och ansvarstagande i relation till den digitala strukturen. De försöker hantera situationen tillsammans.

\title{
Det upplösta klassrummet
}

Det blir tydligt att distansutbildningen skapar en ovan åtskillnad mellan undervisningens parter och upplöser det traditionella klassrummets ramar. Gymnasieeleverna följer befintligt schema och parterna befinner sig därmed i samma tid, men i skilda rum. Förändringen måste hanteras av både elever och lärare i ett kaotiskt nu, utan förberedelse.

Gymnasieläraren Karin beskriver en situation som uppstår när kommunen skyndsamt inför ett system för att erbjuda de hemundervisade gymnasieeleverna lunch mot uppvisande av en kupong. Febril aktivitet skapas i det digitala klassrummet strax innan Karins lektion:

\begin{abstract}
"Eleven meddelar att de är på en pizzeria och att scanningen av koden inte fungerar. [...] Jag går in på informationssidan i frågan och meddelar eleverna vilket telefonnummer de ska ringa och jag hör hur en annan elev ringer upp kommunen och för en dialog. Det är tydligen överhettning i systemet så eleverna får instruktioner om att de ska lämna namn och personnummer till restaurangen. Eleven tackar mig för hjälpen och sedan lägger de på. När jag väl går in i mitt digitala klassrum möts jag av två elever som direkt ropar till mig att de inte kan registrera sig för lunchkupongerna. En elev meddelar hur han ska göra och jag säger åt eleven att det är bättre om de andra hjälper honom för nu ska vi ha lektion. Tre minuter senare dyker en elev upp i klassrummet och ropar glatt att idag blir det svenska på en pizzeria. Han meddelar att de äntligen kunnat beställa sin mat så nu måste de sitta och vänta på den [...]."
\end{abstract}

\section{Gymnasieläraren Karin}

Utifrån en etisk-politisk praxis hanterar Karin de kaotiska förändrade strukturella förutsättningarna som skapar nya arbetsuppgifter. Hon har tillit till sin egen förmåga att hantera den nya praktiken och söker information, instruerar elever, delegerar ansvar och påbörjar sin digitala undervisning. Även eleverna behöver kunna känna tillit till att de kan hantera nya situationer, på egen hand och med handledning. De utforskar nuet tillsammans med Karin och dugliggör varandra via ansvarstagande, handlingskraft, nyfikenhet och flexibilitet.

Gränserna mellan den professionella arenan, som skolan utgör, och den privata suddas också ut:

"Plötsligt dyker en av eleverna upp i bild och han sitter uppenbarligen i köket och röker cigarr. Jag blir ganska förvånad över bilden och vet inte riktigt vad jag säga men förmedlar att i mina klassrum är rökning inte tillåten. Eleven släcker cigarren och reser sig upp och frågar om det fungerar med dans. Innan jag hinner svara så dansar eleven något som tydligen heter coaster step. [...] Sedan tar han fram en inhalator och inhalerar två intryckningar. Jag meddelar på skämt att jag ju sagt att det inte får förekomma några otillåtna substanser på min lektion. Eleven vänder då på datorn och visar sina mediciner och meddelar tydligt att han faktiskt har astma." 


\section{Gymnasieläraren Karin}

Eleverna befinner sig i hemmiljö men möter Karin i ett digitalt klassrum. Parterna bjuds därmed in i varandras privata sfärer. Lärarens förväntningar är att eleverna ska följa ramarna för en traditionell lektion, men vissa elever uppvisar andra beteenden. Karin är ovan vid det och förvånad över att behöva upplysa eleverna om de sociala ramarna. Återigen behöver hon agera utifrån en etisk-politisk praxis. Agerandet uppmärksammas varsamt då rökningen poängteras med humor. Eleven och Karin hanterar situationen och skapar de gemensamma förhållningsreglerna tillsammans. De dugliggör varandra och utforskar det okända med nyfikenhet.

\section{Diskussion}

Vad kan då skolan lära av den svarta svan som landar där, våren 2020? I den relationella brännpunkt som uppstår i skolan under inledningen av covid-19-pandemin i Sverige, blir det tydligt hur en invand skolmiljö förändras. När det nya viruset gör entré anpassas lärares handlingar i både grund- och gymnasieskolan i relation till de många obekanta situationer som uppstår. Skolan fungerar både i förhållande till det som varit och inte längre är etablerat och till det som blir till men ännu inte är etablerat. Dessa svårfångade och komplexa händelser verkar också aktivera lärares känslighet för sina inneboende förmågor och sin moraliska kompass. Det blir centralt att förmå sig själv att vara uppmärksam, nyfiken och agera ansvarsfullt. En respons- och ansvarskapabel pedagogik förstärks då den gängse lärarpraktiken delvis är satt ur spel. När moraliska dilemman identifieras i skolpraktiken agerar Emil, Sofia och Karin i ett lokalt perspektiv, förankrat på den egna skolan i relation till de egna eleverna, kollegorna och vårdnadshavarna. De är även på ett politiskt plan, i ett nationellt perspektiv, medvetna om sitt och skolans ansvar gentemot samhället. I krisens "nu" brottas de med en ökad arbetsbelastning, frågor om likvärdighet, glapp mellan individers digitala kunskaper liksom förändrade strukturer och förhållningssätt i de upplösta klassrummen. Vi anar våndan och delar oklarheterna som får både lärare och elever att bryta mot vissa uttalade och outtalade normer för att tillsammans bidra till att situationen blir "hanterbar".

Här är det viktigt att tydliggöra att respons- och ansvarskapabel pedagogik inte är någon "ny" form av pedagogik utan är något som alltid existerar mer eller mindre i de relationella pedagogiska processerna. En sådan pedagogik utvecklas när lärare och elever ges möjlighet att få insikt i sin roll i och koppling till sociala och politiska villkor. När etisk-politisk problematik identifieras i form av till exempel socioekonomiska betingelser som elevers tillgång till internet och mat på bordet eller lärares eventuella digitala kunskapsglapp, så kan sådana strukturella ojämlikheter, behov och erkännande av dessa skapa en intensifierad koppling till det som är väsentligt och yrkesmoraliskt rätt. Genom att inse vikten av att nära konfronteras med olika aspekter av tillkortakommanden eller obehag kan det bli möjligt att faktiskt se kaos, sårbarhet och otillräcklighet som en tillgång. Den svarta svan som utmanat lärarnas vardagliga praktik har påmint oss om att "det förflutna aldrig är stängt, inget är färdigt en gång för alla. Det finns inget sätt att ta tillbaka något igen, att ställa in tiden rätt eller sätta världen tillbaka på sin snurrande axel. Det finns ingen möjlighet att radera” ([6], s 264, författarnas översättning). Vi kan istället förstå situationen som en omfamning och utmaning av lärarna både 'på bredden' och 'på djupet' [7].

Under höstterminen vistas Emil, Sofia och Karin liksom alla andra lärare fortfarande i en skola som inte riktigt vet hur den ska fungera i relation till covid-19. Hur ska de lyckas följa Folkhälsomyndighetens rekommendationer när skolan åter är befolkad av alla elever? Hur ska undervisningen bedrivas? Kommer även gymnasielärarna, precis som lärarna i grundskolan, tvingas hantera parallella undervisningspraktiker? Vad ska vägleda agerandet? Hur ska vi tänka när skolan fortsätter att innebära en turbulent tillvaro? Det vi kan göra beskriver Donna Haraway [8] som möjligheten att "mönstra om" - utveckla nya mönster av tänkande, kännande och görande - och att erkänna oss själva som sårbara, som en del av en orolig värld. Ett sådant förhållningssätt kan bidra till lärares assistans av varandra, till deras kollektiva göranden, erfarenheter och kunskaper. 


\section{Författare}

Linda Ekström Lind arbetar som gymnasielärare i svenska, historia och religion på Folkungaskolan i Linköping. Linda brinner för undervisning och då särskilt för att utveckla de didaktiska strukturer som formar en explicit undervisning. En väg att nå dit har för henne varit att praktisera ett språk- och kunskapsutvecklande arbetssätt i kombination med bedömning för lärande. För Linda är det elevernas lärande som står i fokus och i fokus för lärandet står språket. Epostadress: linda.ekstromlind@linkoping.se

Anna Martín Bylund är doktor i pedagogiskt arbete med språkvetenskaplig inriktning. Hon arbetar som lektor vid institutionen för beteendevetenskap och lärande (IBL) vid Linköpings universitet. Hennes forskning handlar främst om språk, litteracitet och flerspråkighet i olika utbildningskontexter. Hon har också forskat om transnationella familjer, bland annat om dessa personers komplexa relationer till plats, liksom om hur de använder olika digitala applikationer för att genom videokommunikation försöka överbrygga geografiska och känslomässiga avstånd. Tidigare har Anna också arbetat som gymnasielärare i språk. E-postadress: anna.martin.bylund@liu.se

Linnéa Stenliden är docent i pedagogiskt arbete med inriktning mot digitala medier. Hon arbetar som lektor vid institutionen för beteendevetenskap och lärande (IBL) på Linköpings universitet. I sin forskning har hon intresserat sig för digitala medier i olika sammanhang. Centrala teman i forskningen handlar om digital kommunikation, multimodala, digitala läspraktiker och elevers representation av kunskap (kunskapsvisualisering). Hon har många års erfarenhet av att driva forskningsprojekt i nära samarbete med lärare i skolan. Linnea har också tidigare arbetat som lärare och skolledare på grundskola och gymnasium. E-postadress: linnea.stenliden@liu.se
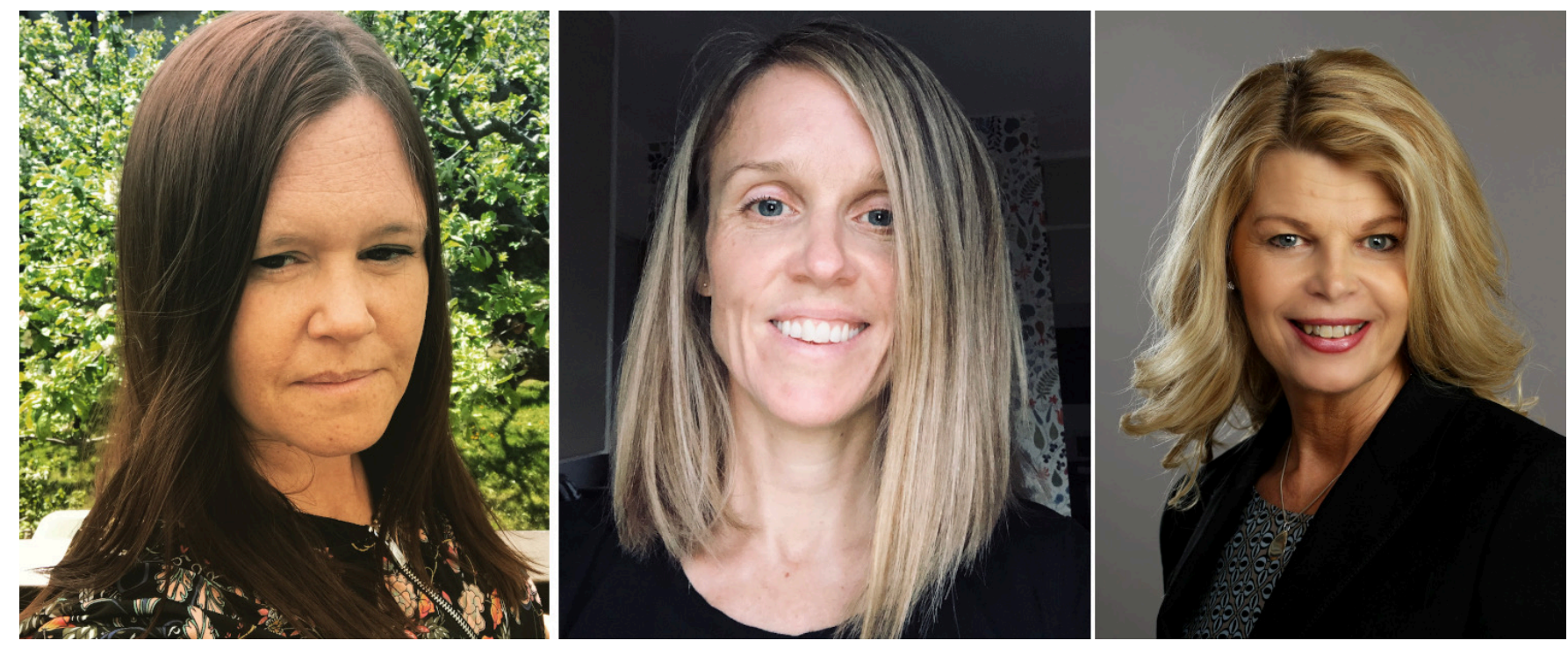

Författarna Linda Ekström Lind, Anna Martín Bylund och Linnéa Stenliden.

\section{Fotnoter}

1. UNESCO: COVID-19 Educational Disruption and Response. Hämtad den 15 maj 2020 från: https://en.unesco.org/themes/education-emergencies/coronavirus-school-closures

2. Utbildningsdepartementet: Förbättrade möjligheter till utbildning ska hjälpa Sverige genom krisen. Hämtad den 15 maj 2020 från 
https://www.regeringen.se/pressmeddelanden/2020/03/forbattrade-mojligheter-till-utbildning-skahjalpa-sverige-genom-krisen/

\section{Referenser}

1. Taleb NN. The black swan: the impact of the highly improbable. New York: Random House Trade Paperbacks; 2010.

2. Biesta G. Bortom lärandet, Demokratisk utbildning för en mänsklig framtid. Lund: Studentlitteratur; 2006.

3. God forskningssed. Stockholm: Vetenskapsrådet; 2017.

4. Biesta G, Filippakou O, Wainwright E, Aldridge D. Why educational research should not just solve problems, but should cause them as well. British educational research journal. 2019;45(1).

5. Bozalek V, Zembylas M. Towards a response-able pedagogy across higher education institutions in post-apartheid South Africa: an ethico-political analysis. Education as change. 2017;21(2).

6. Barad K. Quantum Entanglements and Hauntological Relations of Inheritance: Dis/continuities, SpaceTime Enfoldings, and Justice-to-Come. Derrida today. 2010;3(2).

7. Stenliden L, Bylund AM, Landkvist L, Lind LE, Lundberg SK, Stenmark H, Wilhelmsson C. Lärares digitala kompetens före, under och efter covid-19. SocArXiv. 2020;.

8. Haraway D. Staying with the Trouble: Making Kin in the Chthulucene. Durham: Duke University Press; 2016. 